\title{
Self rating of health is associated with stressful life events, social support and residency in East and West Berlin shortly after the fall of the wall
}

\author{
Thomas Hillen, Rainer Schaub, Angelika Hiestermann, Wolf Kirschner, Bernt-Peter Robra
}

\begin{abstract}
Study objective-To compare the health status and factors influencing the health of populations that had previously lived under different political systems.

Design-Cross sectional health and social survey using postal interviews. The relation between self reported health and psychosocial factors (stressful life events, social support, education, health promoting life style and health endangering behaviour) was investigated. To determine EastWest differences a logistic regression model including interaction terms was fitted.
\end{abstract}

Setting-East and West Berlin shortly after reunification 1991.

Participants-Representative sample of 4430 Berlin residents aged 18 years and over (response rate $63 \%$ ).

Results-Of all respondents, $15.4 \%$ rated their health as unsatisfactory. Residents of East Berlin rated their health more frequently as unsatisfactory than residents of West Berlin $\left(\mathrm{Or}_{\text {age adjusted }}=1.29,95 \% \mathrm{CI} 1.08\right.$, 1.52), these differences occurred predominantly in the over 60 years age group. Logistic regression showed significant independent effects of stressful life events, social support, education, and health promoting life style on self rated health. The effects of education and health promoting life style were observed to be more pronounced in the western part of Berlin. Old age and female sex showed a stronger association with unsatisfactory health status in the eastern part of Berlin.

Conclusions-For subjects aged over 60 years there was evidence that living in the former East Berlin had an adverse effect on health compared with West Berlin. The impact of education and a health promoting lifestyle on self rated health seemed to be weaker in a former socialist society compared with that of a Western democracy. This study supports an "additive model" rather than a "buffering model" in explaining the effects of psychosocial factors on health.

( $F$ Epidemiol Community Health 2000;54:575-580)

Self rating of health is an important indicator of general health ${ }^{1-4}$ and has proved to be a useful instrument for national and transnational epidemiological studies on inequalities in health..$^{5-7}$ Though unfeasible until the end of the cold war in 1989, comparisons of self ratings of health within and between the socially and politically divergent populations of East and West Berlin would have been of particular interest as confounding factors would have been reduced because of their geographical and cultural proximity.

Residents of the former East experienced relative deprivation in comparison with the former West with a lower standard of living and lower spending per capita on health care. ${ }^{8}$ However, data on objective health indicators, such as life expectancy, showed that differences between East and West Berlin were minor. ${ }^{9}$ The far reaching changes resulting from reunification were observed to have little impact on health. ${ }^{10-12}$ This lead to the assumption that almost equal self rated health status would be observed among residents of East and West Berlin.

Previous studies have repeatedly found that psychosocial factors such as stress and disposal of resources influence health status. Much of the research on stressful life events, ${ }^{13}{ }^{14}$ socioeconomic status, ${ }^{15}$ social support, ${ }^{16}{ }^{17}$ and lifestyle factors ${ }^{18-20}$ has been undertaken in Western societies. The majority of the established stressful life events relate to unemployment or financial problems and were almost unknown in socialist societies. The principles of the socialist ideology included the levelling out of social class differences and the buttressing of state institutions to diminish reliance on social support from the "unobservable" nuclear family. In the socialist society less emphasis was laid on the person's responsibility for their own health and happiness (such as lifestyle factors). Consequently, psychosocial factors were expected to be less predictive for inequalities in health in East Berlin compared with West Berlin.

Conflicting findings can be observed in the study of the interplay between psychosocial factors and their effects on health. ${ }^{21}$ The majority of obtained results provide evidence to support the "additive model" where both stressors and resources have an independent effect on health. ${ }^{13}$ However, some studies have found that resources do not exert a protective effect unless stressors are also present, confirming the "buffering model". ${ }^{22}$ In this paper it has been assumed that an additive model applies to the respective populations of Berlin.

East-West comparisons provide an important means to test the generalisability of previous sociomedical research undertaken in Western societies to societies in transition and potentially developing countries. The aim of this study was to test the following hypotheses: (a) similar overall health status in East compared with West Berlin would be observed shortly after the fall of the wall; (b) psychosocial factors such as 
stressful life events, education and social support would show stronger association with health in West Berlin compared with East Berlin; and (c) combined effects of stress and resources on health would not be apparent in East or West Berlin.

\section{Methods}

SAMPLE

In 1991, a representative Berlin Health and Social Survey was conducted for the Berlin Senatorial Administration for Health and Social Services by the Epidemiologische Forschung Berlin (EFB). A mailed questionnaire was sent to German residents of Berlin older than 18 years randomly chosen from the population registry (=original sample). This was followed by telephone reminders to nonresponders. Persons aged 60 years or older were oversampled to allow a detailed analysis according to age and sex (table 1). In total, 4430 completed questionnaires were received (=final sample). The overall responserate was $63 \%$. The survey was representative of 1543835 residents aged 18 years and over in West Berlin, of whom 459473 (29.8\%) were over 60 years, and 857957 residents aged over 18 years in East Berlin, of whom 191470 $(22.3 \%)$ were over 60 years

Very few differences were observed in the distributions of sampling characteristics (age, sex, and area of residence) between the final sample and the original sample. ${ }^{23}$ The proportion of widowed persons and the number of diabetics in the final sample were in agreement with expected values from other demographic surveys and a diabetes register.

A telephone follow up was carried out to investigate reasons for non-response. This exercise was limited to West Berlin because of the widespread lack of telephone connections in East Berlin. Though analysis revealed differences in prevalence of functional limitations between responders and non-responders in the over 60 years age group, differences were negligible among younger subjects. As similar information was not available for East Berlin, and as conservative estimates of the prevalence of disability and poor health should be derived, the present analysis made no correction for the under-representation of functional limitations

Weighting factors were calculated to correct for differences regarding age, sex and area of residence between the original and the final sample.

MEASUREMENTS

(1) The self rated health status was based on the participants response to the question "How would you describe your present health status?

Table 1 Number of participants included in the study by age, sex and region and response rates

\begin{tabular}{|c|c|c|c|c|c|c|}
\hline & \multicolumn{3}{|c|}{ West Berlin } & \multicolumn{3}{|c|}{ East Berlin } \\
\hline & $\begin{array}{l}\text { Response } \\
\text { rate (\%) }\end{array}$ & $n$ (total) & $n$ (male) & $\begin{array}{l}\text { Response } \\
\text { rate (\%) }\end{array}$ & $n$ (total) & $n$ (male) \\
\hline $18-60$ years & 64.1 & 1803 & 905 & 63.4 & 1054 & 489 \\
\hline$>60$ years & 59.0 & 1100 & 437 & 66.1 & 473 & 185 \\
\hline Total & 62.6 & 2903 & 1342 & 64.4 & 1527 & 674 \\
\hline
\end{tabular}

Excellent, good, satisfactory, poor, bad". For dichotomous analysis, self ratings of health were divided into "at least satisfactory" (excellent, good, satisfactory) and "unsatisfactory" (poor, bad).

(2) Stressful life events: an inventory of 10 stressful life events was constructed based on the inventory developed by Rosengrens ${ }^{13}$ : (a) caregiver to a dependant person during the past year, (b) worries about family members, (c) death of a spouse within the past year, (d) divorce within the past year, (e) change of residence within the past year, (f) insufficient recognition at the workplace, (g) current unemployment, (h) threatening loss of employment, (i) dissatisfaction with financial situation, and (j) feelings of being overcharged.

(3) Resources: social support was represented by the presence or absence of an sympathetic partner and satisfactory extrafamilial social contacts. Participants were classified as having a sympathetic partner if, firstly, they were living together with a spouse or partner and, secondly, they felt their partner to be sufficiently caring. Extrafamilial social contacts were regarded as satisfactory if, firstly, participants reported having a friend outside of the household they could not do without, and, secondly, they felt generally satisfied with their relationships with friends, neighbours and acquaintances.

Education was represented by the length of formal schooling. Participants were classified into three groups: less than Grade 10, Grade 10 equivalent, and more than Grade 10 .

Health promoting practices were coded when participants reported (a) having regular physical exercise for at least " 1 to 2 hours per week", (b) setting sufficient time aside for relaxation "always" or "very frequent", (c) taking exercise in the fresh air "regular" or "very often", and (d) having participated at least "once" in health promotion programmes. Participants were grouped into those with "3-4", "1-2", and "none" health promoting practices.

Health endangering behaviour was represented by current smoking status, alcohol intake (men more than $60 \mathrm{mg}$ of alcohol per day and women more than $20 \mathrm{mg}$ per day) and presence of obesity (body mass index $>25$ $\mathrm{kg} / \mathrm{m}^{2}$ ). The number of adverse habits and conditions reported by participants were also counted up.

Three age groups were constructed: 18 to 39 years, 40 to 60 years, and over 60 years.

\section{STATISTICAL ANALYSIS}

Prevalence rates were calculated using weighted data as described above. When inference statistics was performed data were not weighted. Odds ratios (OR) were determined by logistic regression. Statistical significance of interactions among variables was examined by the likelihood ratio test statistic. Interactions leading to a significant improvement over the main effects only model were included to the final logistic regression model. In the presence of interaction odds ratios were estimated as reported elsewhere. ${ }^{24}$ The data analysis was performed by SPSS for Windows Version 6.0. 


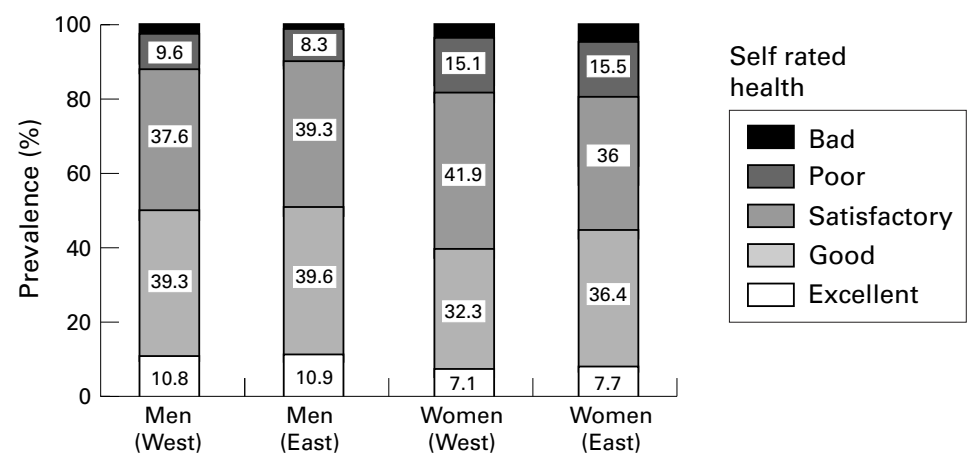

Figure 1 Self rated health status of 4430 Berlin residents by sex and residence in West or East Berlin shortly after German reunification.

Table 2 Odds ratios of unsatisfactory self rated health status for residents of East Berlin compared with residents of West Berlin shortly after German reunification

\begin{tabular}{lll}
\hline Age group & OR & $95 \% C I$ \\
\hline$<40$ & $1.05^{\star}$ & $0.70,1.60$ \\
$40-60$ & $0.97^{\star}$ & $0.72,1.31$ \\
$>60$ & $1.42^{\star}$ & $1.12,1.80$ \\
Total & $1.29 \dagger$ & $1.08,1.52$ \\
\hline
\end{tabular}

*Adjusted for sex. †Adjusted for age (continuous values) and sex.

\section{Results}

Health was rated as excellent by $9 \%$, as good by $36.4 \%$, as satisfactory by $39 \%$, as poor by $12.4 \%$, and as bad by $3.2 \%$ of the Berlin population aged over 18 years. When these results were dichotomised, $15.6 \%$ of the participants rated their health as unsatisfactory. Data on self rated health are given by sex and region (West/ East Berlin) in figure 1.

After adjusting for age and sex, the odds ratio of unsatisfactory self rated health status for residents from East Berlin compared with those from West Berlin was 1.29 (95\% CI 1.08, 1.52). The age stratified analysis showed statis- tically significant differences only in the age group over 60 years (table 2).

Univariate associations between risk factors and unsatisfactory self rated health status are given separately for East and West Berlin in table 3. Female sex and age were associated with unsatisfactory health status in both parts of Berlin. Subjects exposed to stressful life events were at risk of reporting an unsatisfactory health status and the risk increased with the number of these events. Results were similar concerning resources: higher levels of social support, education and health promoting life style were associated with lower odd ratios of unsatisfactory health status. These psychosocial factors showed similar relations to self rated health in East and West Berlin, but associations tended to be weaker in East Berlin, particularly with regard to the health promoting lifestyle and education. Health endangering behaviour was not related to self rating of health in East or West Berlin.

Table 4 illustrates how self rated health was influenced by different levels of stress and social support. After stratifying for region and age, unsatisfactory health status tended to relate to level of social support independently of the exposition to stressful life events. This was confirmed by the multivariate analysis, where the likelihood ratio test statistic for the interaction term "stressful life events/social support" did not reach statistical significance.

Table 5 shows the multivariable logistic regression model to predict self ratings of health. The odds ratios for sex, age, education and health promoting lifestyle are given separately for East and West Berlin as they showed significant interactions with region. The psychosocial factors education and health promoting life style were more strongly associated with unsatisfactory self rated health status

Table 3 Prevalence of risk factors and their univariate association with unsatisfactory self rated health status in West and East Berlin shortly after German reunification

\begin{tabular}{|c|c|c|c|c|c|c|}
\hline \multirow[b]{2}{*}{ Risk/protective factor } & \multicolumn{3}{|l|}{ West Berlin } & \multicolumn{3}{|l|}{ East Berlin } \\
\hline & PrevalenceS & $O R \boldsymbol{q}$ & $95 \% C I$ & PrevalenceS & $O R \boldsymbol{\Psi}$ & $95 \% C I$ \\
\hline \multicolumn{7}{|l|}{ Sex } \\
\hline Male & $45.6 \%$ & 1 & & $46.5 \%$ & 1 & \\
\hline Female & $54.4 \%$ & $1.35^{\star}$ & $1.10,1.66$ & $53.5 \%$ & $1.79^{\star}$ & $1.34,2.39$ \\
\hline \multicolumn{7}{|l|}{ Age $(y)$} \\
\hline$<40$ & $36.4 \%$ & 1 & & $46.6 \%$ & 1 & \\
\hline $40-60$ & $32.8 \%$ & $2.67 \dagger$ & $1.95,3.66$ & $35.1 \%$ & $2.48 \dagger$ & $1.66,3.71$ \\
\hline$>60$ & $30.8 \%$ & $4.50 \dagger$ & $3.35,6.04$ & $18.3 \%$ & $6.00 \dagger$ & $4.11,8.74$ \\
\hline \multicolumn{7}{|l|}{ Stressful life events } \\
\hline $\mathrm{n}=0$ & $32.2 \%$ & 1 & & $18.6 \%$ & 1 & \\
\hline $\mathrm{n}=1-2$ & $49.3 \%$ & $1.88 \ddagger$ & $1.48,2.40$ & $48.7 \%$ & $1.31 \ddagger$ & $0.91,1.89$ \\
\hline $\mathrm{n}=\geqslant 3$ & $17.5 \%$ & $2.81 \ddagger$ & $2.05,3.85$ & $32.6 \%$ & $2.15 \ddagger$ & $1.40,3.29$ \\
\hline \multicolumn{7}{|l|}{ Social support } \\
\hline Partner and friends & $44.7 \%$ & 1 & & $50.6 \%$ & 1 & \\
\hline Partner or friends & $46.3 \%$ & $1.41 \ddagger$ & $1.13,1.76$ & $42.6 \%$ & $1.67 \ddagger$ & $1.24,2.25$ \\
\hline No partner, no friends & $9.0 \%$ & $2.68 \ddagger$ & $1.92,3.73$ & $6.8 \%$ & $1.93 \ddagger$ & $1.13,3.29$ \\
\hline \multicolumn{7}{|l|}{ Education } \\
\hline More than grade 10 & $28.6 \%$ & 1 & & $33.3 \%$ & 1 & \\
\hline Grade 10 & $29.2 \%$ & $1.52 \ddagger$ & $1.11,2.07$ & $35.9 \%$ & $0.75 \ddagger$ & $0.50,1.12$ \\
\hline Less than grade 10 & $42.2 \%$ & $1.69 \ddagger$ & $1.28,2.25$ & $30.8 \%$ & $1.13 \ddagger$ & $0.80,1.61$ \\
\hline \multicolumn{7}{|l|}{ Health promoting lifestyle } \\
\hline 3-4 positive practices & $26.5 \%$ & 1 & & $18.4 \%$ & 1 & \\
\hline 1-2 positive practices & $60.6 \%$ & $2.28 \ddagger$ & $1.70,3.06$ & $70.0 \%$ & $1.16 \ddagger$ & $0.79,1.70$ \\
\hline 0 positive practices & $12.8 \%$ & $2.86 \ddagger$ & $2.00,4.11$ & $11.6 \%$ & $2.24 \ddagger$ & $1.37,3.66$ \\
\hline \multicolumn{7}{|c|}{ Health endangering behaviour } \\
\hline 0 negative habits & $29.0 \%$ & 1 & & $30.9 \%$ & 1 & \\
\hline $1-2$ negative habits & $68.4 \%$ & $1.32 \ddagger$ & $1.04,1.67$ & $66.6 \%$ & $0.93 \ddagger$ & $0.69,1.26$ \\
\hline 3 negative habits & $2.6 \%$ & $1.13 \ddagger$ & $0.53,2.39$ & $2.5 \%$ & $1.19 \ddagger$ & $0.47,3.02$ \\
\hline
\end{tabular}

*Adjusted for age (continuous values), †adjusted for sex, ładjusted for age (continuous values) and sex, \data weighted, $\lceil$ data unweighted. 
Table 4 Prevalence of unsatisfactory self rated health status stratified for region, age, stressful life events and social support shortly after German reunification

\begin{tabular}{|c|c|c|c|c|c|}
\hline \multirow[b]{2}{*}{ Region } & \multirow[b]{2}{*}{ Age (y) } & \multirow[b]{2}{*}{$\begin{array}{l}\text { Stressful life } \\
\text { events }(n)\end{array}$} & \multicolumn{3}{|c|}{$\begin{array}{l}\text { Prevalence (\%) of unsatisfactory self rated health } \\
\text { status by social support }\end{array}$} \\
\hline & & & $\begin{array}{l}\text { Partner and } \\
\text { friends }\end{array}$ & $\begin{array}{l}\text { Partner or } \\
\text { friends }\end{array}$ & $\begin{array}{l}\text { No partner, } \\
\text { no friends }\end{array}$ \\
\hline \multirow[t]{6}{*}{ West Berlin } & $<40$ & $0-2$ & 3.4 & 5.7 & 8.9 \\
\hline & & $\geqslant 3$ & 9.3 & 12.0 & 12.8 \\
\hline & $40-60$ & $0-2$ & 9.4 & 17.6 & 32.1 \\
\hline & & $\geqslant 3$ & 30.3 & 25.8 & 25.0 \\
\hline & $>60$ & $0-2$ & 19.2 & 26.7 & 45.3 \\
\hline & & $\geqslant 3$ & 25.0 & 28.9 & 61.5 \\
\hline \multirow{6}{*}{ East Berlin } & $<40$ & $0-2$ & 4.3 & 6.3 & 6.9 \\
\hline & & $\geqslant 3$ & 13.0 & 8.5 & 20.0 \\
\hline & $40-60$ & $0-2$ & 10.0 & 15.7 & 14.3 \\
\hline & & $\geqslant 3$ & 12.8 & 29.8 & 40.0 \\
\hline & $>60$ & $0-2$ & 20.4 & 39.4 & 46.7 \\
\hline & & $\geqslant 3$ & 30.0 & 36.4 & 50.0 \\
\hline
\end{tabular}

†Data weighted.

Table 5 Multivariable logistic regression model to predict unsatisfactory self rated health status among residents of West and East Berlin shortly after German reunification*

\begin{tabular}{|c|c|c|c|c|c|c|}
\hline \multirow[b]{2}{*}{ Risk factor } & \multicolumn{2}{|c|}{ Overall } & \multicolumn{2}{|c|}{ West Berlin } & \multicolumn{2}{|c|}{ East Berlin } \\
\hline & $O R$ & $95 \% C I$ & $O R$ & $95 \% C I$ & OR & $95 \% C I$ \\
\hline \multicolumn{7}{|l|}{ Sex } \\
\hline Male & & & 1 & & 1 & \\
\hline Female & & & 1.16 & $0.94,1.43$ & 1.65 & $1.23,2.21$ \\
\hline \multicolumn{7}{|l|}{ Age $(y)$} \\
\hline$<40$ & & & 1 & & & 1 \\
\hline $40-60$ & & & 2.75 & $1.98,3.83$ & 2.32 & $2.12,2.55$ \\
\hline$>60$ & & & 4.59 & $3.31,6.36$ & 5.69 & $5.17,6.26$ \\
\hline \multicolumn{7}{|l|}{ Stressful life events } \\
\hline $\mathrm{n}=0$ & 1 & & & & & \\
\hline $\mathrm{n}=1-2$ & 1.54 & $1.25,1.88$ & & & & \\
\hline$n=\geqslant 3$ & 2.18 & $1.68,2.83$ & & & & \\
\hline \multicolumn{7}{|l|}{ Social support } \\
\hline Partner and friends & 1 & & & & & \\
\hline Partner or friends & 1.47 & $1.22,1.76$ & & & & \\
\hline No partner, no friends & 2.33 & $1.75,3.11$ & & & & \\
\hline \multicolumn{7}{|l|}{ Education } \\
\hline More than grade 10 & & & 1 & & 1 & \\
\hline Grade 10 & & & 1.47 & $1.07,2.01$ & 0.71 & $0.59,0.86$ \\
\hline Less than grade 10 & & & 1.54 & $1.15,2.06$ & 1.23 & $1.18,1.29$ \\
\hline \multicolumn{7}{|l|}{ Health promoting lifestyle } \\
\hline 3-4 positive practices & & & 1 & & 1 & \\
\hline 1-2 positive practices & & & 2.23 & $1.65,3.00$ & 1.25 & $0.70,2.22$ \\
\hline 0 positive practices & & & 2.88 & $2.00,4.13$ & 2.53 & $1.22,5.24$ \\
\hline \multicolumn{7}{|c|}{ Health endangering behaviour } \\
\hline 0 negative habits & 1 & & & & & \\
\hline 1-2 negative habits & 1.02 & $0.84,1.23$ & & & & \\
\hline 3 negative habits & 0.82 & $0.45,1.48$ & & & & \\
\hline
\end{tabular}

${ }^{\star}$ Odds ratios were obtained in a single logistic regression model including the following main effects and interaction terms: region, sex, age, stressful life events, social support, education, health promoting lifestyle, health endangering behaviour, region ${ }^{\star} \mathrm{sex}$, region ${ }^{\star}$ age, region ${ }^{\star}$ education, region $^{\star}$ health promoting lifestyle. Only significant interaction terms (likelihood ratio test statistic: $\mathrm{p} \leqslant 0.1$ ) were included to the model.

in the western part of Berlin, whereas sex and age showed stronger associations in the eastern part of Berlin.

\section{Discussion}

German reunification enabled the first direct comparison of the health status of two populations that had previously lived under different political and economic systems. The Berlin Health and Social Survey in 1991 provided data on a number of health, lifestyle and social characteristics in a large representative sample of East and West Berliners. This study focuses on self ratings of health. As in most other studies, self rated health status was based on the reply to one global question ("How would you describe your current health status?"). This measure of health status is attractively simple and prospectively valid. It has previously been shown to be predictive of objective health measures such as disease, health care services use and mortality. ${ }^{2-42526}$

In discussing the results, some limitations of this study have to be considered. The study examined the urban population of Berlin and it is difficult to say to what extent its results apply to the entire population of Germany. Before reunification East Berlin was the capital of East Germany and experienced an influx of young and healthy professionals, whereas West Berlin was an appendix of West Germany undergoing a less positive selective migration. This is underlined by a higher life expectancy observed in the population of East Berlin compared with the East German average in 1986, conversely this indicator was lower in the West Berlin population than in West Germany as a whole. ${ }^{27}{ }^{28}$ However, there was a considerable westward migration of professionals within Berlin after 1989. ${ }^{9}$ This could have counterbalanced some of the aforementioned selective migration. This study did not account for migration.

Unfortunately data on social stratification and self ratings of health before reunification were not available for East Berlin, research of this kind being unfeasible under the socialist regime. Ideally, measurements of self rated health status before and after reunification would have been undertaken. This would have enabled the differentiation to be made between both the long term effects of living in either East or West Berlin and the short-term effects of German reunification.

The population of Berlin was found to have similar health status to other European countries, ${ }^{29}$ but worse than that of the United States. ${ }^{70}$ As hypothesised, differences in the prevalence of unsatisfactory self rated health between East and West Berlin were relatively small $(\mathrm{OR}=1.29)$, they reached statistical significance however. The explanation, why self ratings of health in East and West Berlin were similar, is threefold.

Firstly, there were no major differences in health between the populations of East and West Berlin before the fall of the wall. This is reflected by a similar overall life expectancy in both parts of Berlin at this time. ${ }^{27}$ The absence of adverse health effects from material deprivation in the former East Berlin could have been a result of the following: (a) The selective migration process as detailed earlier. (b) Previous research has shown equality in the distribution of income to be associated with positive self ratings of health independent of the effect of household income. ${ }^{5}$ International comparisons reported exceptional equality in the distribution of income for former East Germany. ${ }^{31}$ (c) Unemployment and high job strain are associated with poor health. ${ }^{32-34}$ Compared with West Berlin, employment rates before reunification were higher and the job strain was lower in former East Berlin, where employment was provided for everyone who wanted it. ${ }^{835}$

Secondly, the stress resulting from the fall of the Berlin wall did not have a detrimental effect on the health of most East Berliners. This is confirmed by other studies: (a) The cardiovas- 
cular risk factor profile remained stable between 1982 and $1994 .^{12}$ (b) There was no increase in mental illness relative to reunification. ${ }^{10}$ (c) Life expectancy decreased by 0.9 years in East Germany in 1990, and reached the 1989 level again in 1992. However, this was solely attributable to higher mortality rates in men under 65 years. The increased number of deaths among men under 45 years were a result of road traffic accidents. Only in men between 45 and 65 years mortality increased attributable to ischaemic heart disease, possibly pointing towards higher stress levels in this group. ${ }^{11}$

Thirdly, the optimistic expectations among East Berliners after reunification could have resulted in more positive self ratings of health. This could have counterbalanced any minor disadvantages in terms of objective health status among East Berliners compared with West Berliners. This applies in particular to younger subjects, as previous research has shown that positive mood induces better self ratings of health in this age group. ${ }^{36}$ In elderly subjects self ratings of health have been reported to be relatively stable over time and insensitive to topical changes. ${ }^{37} 38$

Only among subjects aged over 60 years East/West differences in self ratings of health reached significance. This is consistent with mortality data showing lower survival rates in East compared with West Berlin restricted to elderly subjects. ${ }^{9}$ One explanation could be that elderly subjects are more dependent on the health care system and there was some evidence that services were worse in the East. ${ }^{39}$

This study demonstrated that women rated their health as being poorer than men. This corresponds to the findings of most international research ${ }^{30}{ }^{40}$ with the exception of one German study. ${ }^{35}$ According to the obtained logistic regression model, this finding cannot be explained by a larger number of stressful life events or by fewer resources. The association of female sex with unsatisfactory perceived health was more pronounced in East Berlin than in West Berlin. This is in keeping with our own data, which showed a higher prevalence of self reported disability among women compared with men in East Berlin $\left(\mathrm{OR}_{\text {ageadiusted }}=1.72\right.$, $95 \%$ CI 1.19, 2.50), but not in West Berlin $\left(\mathrm{OR}_{\text {ageadjusted }}=0.98,95 \% \mathrm{CI} 0.77,1.25\right.$, data not shown). This might be because of the fact that women in former East Germany more frequently had to go to work and bring up their children at the same time (this strain was not included in our stress inventory).

The majority of studies examining effects of the psychosocial factors on health have been undertaken in Western societies and have used objective health parameters (mortality, cardiovascular morbidity) as dependent variables. ${ }^{13}{ }^{41-43}$ This study evaluated the relations between psychosocial factors and self rated health in a Western democracy and a former socialist society. It was observed that psychosocial factors contributed to an explanation of inequalities in self rated health status within both populations. A dose response relation could be found, as the odds of an unsatisfactory
KEY POINTS

- Only in the over 60 years age group did more East than West Berliners rate their health as unsatisfactory shortly after the fall of the wall.

- Female sex and old age (>60 years) showed a stronger association with unsatisfactory self rated health in East than in West Berlin.

- Inequalities in health relating to education and health promoting lifestyle were less pronounced in the former socialist society of East Berlin.

- The beneficial effects of social support on health were found to be independent of the level of stressful life events.

- Health endangering behaviours (smoking, alcohol abuse, and overnutrition) did not contribute to the explanation of differences in self rated health.

health status increased with the level of stress and decreased with the level of available resources. It was hypothesised that the associations between psychosocial factors and self rated health would be more pronounced in the Western part of Berlin. In the multivariate analysis, however, East/West differences in the effects of stressful life events and social support did not reach statistical significance. Apparently it did not take long for comparatively "new" and ubiquitous stressors like unemployment and financial problems to exert their effects on self ratings of health in East Berlin. The lack of East/ West differences in the impact of social support on health can be explained by failures of the socialist regime to diminish reliance on the nuclear family. Because of shortcomings in the planned market system, East Germans were forced to rely on informal social networks to maintain everyday life. ${ }^{44}$

In accord with our hypothesis, social class differences (education) in health were found to be stronger in West than in East Berlin. The former socialist regime preferred the working classes and their members were often more privileged than professional classes. This corresponds to other findings reporting poorer health and health care provisions particularly in members of the professional classes in the former East. ${ }^{45}$ The beneficial effects of a health promoting lifestyle were also found to be more pronounced in West than in East Berlin. This might be explained by the fact that more people in the West considered fitness to be important and participated in mass sports. ${ }^{8}{ }^{46}$

East/West differences in the associations between psychosocial factors and health were observed to lie in the magnitude, rather than in the kind, of association. Because of this, the results of previous research on psychosocial factors and health undertaken in Western societies seems, with some reservations, also to apply to societies in transition.

The negative influence of a health endangering behaviour (such as smoking, alcohol consumption, overnutrition) on morbidity and mortality has been shown repeatedly. ${ }^{47}$ In this 
study these negative behaviours were not associated with the participants' perception of their own health. This is consistent with previous findings that report a lack of association between self rated health and the coronary risk profile. ${ }^{48}$ This could account for difficulties experienced with preventative programmes focusing on health endangering behaviour. This study provides evidence that positive health practices have a much greater effect on self rated health than adverse habits. This corresponds to target number fourteen of the WHO's "regional targets for health for all" to support a health promoting life style. ${ }^{49}$

Evidence of an interactive effect between stressful life events and social support was also investigated. Consistent with our hypothesis, both subjects who were and those who were not exposed to stressful life events, rated their health status better when they had social support. These findings were similar in both East and West Berlin and provide evidence to support the additive model, where both stressors and social support have independent effects on health. As a result, population based interventions reducing stress and improving social support can be expected to have beneficial effects for the majority of participants and not only for certain risk groups.

Funding: the primary data collection was part of a study funded and supervised by the magistrate of Berlin. The present analysis and report of data was independent of sponsors.

Conflicts of interest: none.

1 Barsky AJ, Cleary PD, Klerman GL. Determinants of perceived health status of medical outpatients. Soc Sci Med 1992;34:1147-54

2 Miilunpalo S, Vuori I, Oja P, et al. Self-rated health status as a health measure: the predictive value of self-reported health status on the use of physician services and on mortality in the working-age population. $\mathcal{F}$ Clin Epidemiol 1997 50:517-28.

3 Idler EL, Benyamini Y. Self-rated health and mortality: a review of twenty-seven community studies. $\mathcal{F}$ Health Soc Behav 1997;38:21-37.

4 Moller L, Kristensen TS, Hollnagel H. Self rated health as a predictor of coronary heart disease in Copenhagen, predictor of coronary heart disease in Copenhagen,

5 Kennedy BP, Kawachi I, Glass R, et al. Income distribution, Kennedy BP, Kawachi I, Glass R, et al. Income distribution, socioeconomic status, and self rated health in the

States: multilevel analysis. BMF 1998;317:917-21.
6 Bobak M, Pikhart H, Hertzman C, et al. Socioeconomic factors, perceived control and self-reported health in Russia. A cross-sectional survey. Soc Sci Med 1998;47:26979.

7 Cockerham WC, Kunz G, Lueschen G. Psychological distress, perceived health status, and physician utilization in America and West Germany. Soc Sci Med 1988;26:829-38.

8 Habich R, Landau D, Seifert W, et al. Ein unbekanntes Land- Objektive Lebensbedingungen und subjektives Wohlbefinden in Ostdeutschland. Aus Politik und Zeitgeschichte- Das Parlament 1991;32:13-33.

9 Statistisches Landesamt Berlin. Bevoelkerungsbewegung. In: Statistisches fahrbuch 1992. Berlin: Kulturbuch-Verlag, In: Statistisches

10 Achberger M, Linden M, Benkert O. Psychological distress and psychiatric disorders in primary health care patients in Wall. Soc Psychiatry Psychiatr Epidemiol 1999;34:195-201.

11 Häussler B, Hempel E, Reschke P. Changes in life expectancy and mortality in East Germany after reunification (1989-1992). Gesundheitswesen 1995;57:365-72.

12 Heinemann LA, Garbe E, Classen E, et al. Trends in cardiovascular risk factor profiles in East Germany. Three independent population studies as part of the project MONICA East Germany. Dtsch Med Wochenschr 1998;123 889-95.

13 Rosengren A, Orth Gomer K, Wedel H, et al. Stressful life events, BMF 1993;307:1102-5.

14 Gersten J, Langner T, Eisenberg J, et al. An evaluation of the etiologic role of stressful life- change events in psychological disorders. F Health Soc Behav 1977;18:228-44.

15 Power C, Manor O, Matthews S. The duration and timing of exposure: effects of socioeconomic environment on adult of exposure: effects of socioeconomic environn

16 House J, Landis K. Social relationships and health. Science 1988;241:540-45.
17 Penninx BW, vanTilburg T, Kriegsman DM, et al. Effects of social support and personal coping resources on mortality in older age: the Longitudinal Aging Study Amsterdam. Am F Epidemiol 1997;146:510-19.

18 Baranowski T, Anderson C, Carmack C. Mediating variable framework in physical activity interventions. How are we doing? How might we do better? Am $\mathcal{F}$ Prev Med 1998;15: 266-97.

19 Hakim AA, Petrovitch H, Burchfiel CM, et al. Effects of walking on mortality among non- smoking retired men. $N$ Engl F Med 1998;338:94-9.

20 Chyou PH, Burchfiel CM, Yano K, et al. Obesity, alcohol consumption, smoking, and mortality. Ann Epidemiol 1997; 7:311-17.

21 Badura B. Soziale Unterstützung und chronische Krankheit. Frankfurt am Main: Suhrkamp, 1981

22 Cohen S, Wills TA. Stress, social support, and the buffering hypothesis. Psychol Bull 1985;98:310-57.

23 Kirschner W, Radoschewski M. Gesundheits- und Sozialsurvey Berlin. Berlin: Senatsverwaltung für Gesundheit Berlin, 1993.

24 Hosmer DW, Lemeshow S. Applied logistic regression. New York: Wiley, 1989

$25 \mathrm{Krakau}$ I. Perception of health and use of health care services in a Swedish primary care district. A ten year's perspective. Scand $\mathcal{F}$ Prim Health Care 1991;9:103-8.

26 McGee DL, Liao Y, Cao G, et al. Self-reported health status and mortality in a multiethnic US cohort. Am $\mathcal{F}$ Epidemiol 1999;149:41-6.

27 Casper W, Wiesner G, Bergmann KE. Mortalitaet und Todesursachen in Deutschland- unter besonderer Beruecksichtigung der Entwicklung in den alten und neuen Bundeslaendern. Berlin: Robert Koch Institut, 1995.

28 Statistisches Bundesamt. Statistisches Fahrbuch der Bundesrepublik Deutschland 1989, 1991. Stuttgart: Poeschel, 1991.

29 Kumpusalo E, Pekkarinen H, Neittaanmaki L, et al. Identification of health status dimensions in a working-age population. An exploratory study. Med Care 1992;30:392-9.

30 Ross CE, Bird CE. Sex stratification and health lifestyle: consequences for men's and women's perceived health. $\mathcal{F}$ Health Soc Behav 1994;35:161-78.

31 Menard S. A research note on international comparisons of inequality of income. Social Forces 1986;64:778-93.

32 Dooley D, Fielding J, Levi L. Health and unemployment. Annu Rev Public Health 1996;17:449-65.

33 Morrell S, Taylor R, Quine S, et al. A case-control study of employment status and mortality in a cohort of Australian youth. Soc Sci Med 1999;49:383-92.

34 Wilkins K, Beaudet MP. Work stress and health. Health Rep 1998;10:49-66.

35 Luschen G, Geling O, Janssen C, et al. After unification: gender and subjective health status in East and West Germany. Soc Sci Med 1997;44:1313-23.

36 Abele A, Hermer P. Mood influences on health-related judgements: appraisal of own health versus appraisal of unhealthy behaviours. European fournal of Social Psychology 1993;23:613-25.

37 Dening TR, Chi LY, Brayne C, et al. Changes in self-rated health, disability and contact with services in a very elderly cohort: a 6-year follow-up study. Age Ageing 1998;27:23-

38 Leinonen R, Heikkinen E, Jylha M. Self-rated health and self-assessed change in health in elderly men and women-a five-year longitudinal study. Soc Sci Med 1998;46:591-7.

39 Luschen G, Niemann S, Apelt P. The integration of two health systems: social stratification, work and health in East and West Germany. Soc Sci Med 1997;44:883-99

40 Johnson RJ, Wolinsky FD. Gender, race, and health: the structure of health status among older adults. Gerontologist 1994;34:24-35.

41 Haan M, Kaplan GA, Syme SL. Socioeconomic status and health: old observations and new thoughts. In: Bunker A, ed. Pathways to health. Menlo Park: Kaiser Family Foundation, 1989:76-135.

42 Lynch J, Kaplan GA, Salonen R, et al. Socioeconomic status and carotid atherosclerosis. Circulation 1995;92:1786-92.

43 Kivinen P, Halonen P, Eronen M, et al. Self-rated health, physician-rated health and associated factors among elderly men: the Finnish cohorts of the Seven Countries Study. Age Ageing 1998;27:41-7.

44 Watson P. Explaining rising mortality among men in eastern Europe. Soc Sci Med 1995;41:923-34.

45 Mielck A, Apelt P. Krankheit und soziale Ungleichheit in der DDR: das Beispiel Goerlitz. In: Mielck A,ed. Krankheit und soziale Ungleichheit. Opladen: Leske und Budrich, 1993:243-52.

46 Hoffmeister H, Bellach BM. Die Gesundheit der Deutschen. ein Ost-West Vergleich von Gesundheitsdaten. Berlin: Robert Koch Institut 1995:2.

47 Castelli WP, Wilson PW, Kannel WB, et al. Lipids, risk facors and ischaemic heart disease-Established risk factors and coronary artery disease: the Framingham StudySmoking and hypertension as predictors of cardiovascular risk in population studies. Atherosclerosis 1996;124 (suppl): $1-9$.

48 Fylkesnes K, Forde OH. The Tromso Study: predictors of self-evaluated health-has society adopted the expanded health concept? Soc Sci Med 1991;32:141-6.

49 W.H.O. Global strategy for health for all by the year 2000. Geneva: WHO, "Health for all series", no3, 1981. 